\title{
Recent research and development on sugi (Japanese cedar) structural glued laminated timber
}

\author{
Tomoyuki Hayashi $^{1} \cdot$ Atsushi Miyatake $^{2}$
}

Received: 29 January 2015/Accepted: 12 March 2015/Published online: 9 April 2015

(C) The Japan Wood Research Society 2015

\begin{abstract}
Sugi (Japanese cedar: Cryptomeria japonica) is the most important afforestation species in Japan. Its growing stock has been increasing year by year. Thus, development of new wood products made of sugi has been a national priority for more than two decades. Development of sugi structural glued laminated timber (glulam) was one of the responses to this push. However, in the 1990s, the Japanese glued laminated timber (GLT) industry did not accept sugi as a raw material for glulam, because several problems existed in the wood quality of sugi such as lower strength properties than those of the major imported species. This drawback spurred intensive research on sugi glulam in Japan. The results contributed to the significant revision of the Japanese Agricultural Standard (JAS) for GLT in 2008. The standard permitted the use of various new laminae and products such as a sugi composite GLT beams using different species of laminae with high modulus of elasticity. Although fireproof GLT is not part of the existing JAS for GLT, several fireproof laminated products with 1-h fireproofing performance have been developed since the Japanese Building Standards Law was revised in 2000.
\end{abstract}

Keywords Sugi - Glued laminated timber - Composite glulam · Japanese Agricultural Standard · Fireproof glulam

This review article is published to coincide with the 60th anniversary of the Japan Wood Research Society.

Tomoyuki Hayashi

tomoyuki_hayashi@iwt.akita-pu.ac.jp

1 Institute of Wood Technology, Akita Prefectural University, Noshiro, Akita 016-0876, Japan

2 Forestry and Forest Products Research Institute, Tsukuba, Ibaraki 305-8687, Japan

\section{Introduction}

Sugi (Japanese cedar: Cryptomeria japonica) is the most important afforestation wood species in Japan, comprising $43 \%$ of the country's artificial forests [1]. Its growing stock has been increasing year by year. Thus, much effort has been made to expand the market for sugi. A typical example is the development of sugi structural glued laminated timber (glulam).

More than 60 years have already passed since the first glulam structure was built in Yotsuya, in downtown Tokyo. As of 2012, the total production of glued laminated timber (GLT) in Japan was approximately 1.52 million cubic meters, including non-structural products such as edge-jointed boards and hand rails. At the same time, the amount of imported laminates reached 0.80 million cubic meters [2].

However, up through the 1990s, sugi as a raw material was not readily accepted by the Japanese GLT industry because of the problems in its wood quality: namely, lower strength properties and yield rate than those of major imported species such as Douglas fir (Pseudotsuga menziesii) from North America and European red pine (Pinus sylvestris) from European countries.

Thus, a series of intensive studies on sugi glulam were conducted at ten research institutes in Japan [3], and basic strength data of sugi laminae including finger-jointed laminae were accumulated at the Forestry and Forest Products Research Institute (FFPRI).

The results contributed to the revision of the Japanese Agricultural Standard (JAS) for GLT in 2008 [4]. This revision permitted the use of several new laminae and products such as a sugi composite GLT using different species of laminae with high modulus of elasticity (MOE).

Apart from these efforts, several fireproof laminated products using sugi laminae have been developed and 1-h 
fireproofing wood structures have been constructed since the revision of Japanese Building Standards Law in 2000 [5].

The research and development related to these products is reviewed in the present paper.

\section{Sugi glulam}

Figure 1 shows the production of GLT in Japan. As shown in this figure, a rapid increase of the production of glulam started in the mid 1990s. The prime cause of this trend shift was presumably that a pre-cut processing system used for conventional wooden frames began to prefer precise dimensions and high dimensional stability: one of the inherent advantages of glulam [3]. Another cause was that housing industries began to require the strength reliability of structural wood products after the disasters caused by the Great Hanshin-Awaji earthquake in 1995 [6].

Though the increasing trend of glulam production from 1995 to 2005 changed glulam into a common and popular structural wood product, sugi as a raw material had rarely been accepted by Japanese GLT industry as described in the introduction.

Of course, the relatively higher price of sugi timber than that of other imported species such as Douglas fir and European red pine was another important problem resulting in a decrease of the demand for sugi timber.

As an exception, sugi large-dimensional glulam was used for public structures such as a gymnasium and school, symbolizing the proper utilization of a regional raw commodity [3]. A typical example was the Odate Jukai dome in Akita prefecture, the largest wood structure in Japan.
Table 1 Relation between species and typical strength grades of glulam

\begin{tabular}{lll}
\hline Region & Species & Strength grade \\
\hline Japan & sugi & E65-F225 \\
& & E75-F240 \\
Japan & hinoki, karamatsu & E95-F270 \\
& & E105-F300 \\
Europe & Norway spruce, red pine & E95-F270 \\
& & E105-F300 \\
North America & Douglas fir & E105-F300 \\
& & E120-F330 \\
\hline
\end{tabular}

hinoki: Chamaecyparis obtusa, karamatsu: Larix kaempferi

At the beginning of the 21 st century, however, a drastic decline of the price of sugi round wood resulted in a gradual increase of the production of sugi glulam processed in accordance with JAS for GLT at the time.

Nevertheless, since the JAS for GLT did not assume the use of laminae with a low MOE, one production lot of sugi laminae including low MOE lamina sometimes caused an extensive decrease of the yield rate. Moreover, several restrictions imposed on the shape and size of laminae reduced the selection of laminae, for example, the $5-\mathrm{cm}$ restriction in maximum thickness ruled out the possibility of producing a 2-ply square glulam column with a cross section of $10.5 \times 10.5 \mathrm{~cm}$, which is a common dimension for the structural columns in conventional Japanese wooden houses. Consequently, the production cost of sugi glulam could not be easily reduced as far as the production system was in accordance with JAS for GLT at the time.

As will be described in the next chapter, a series of intensive studies on sugi glulam was conducted at 10
Fig. 1 Production of glued laminated timber (GLT)in Japan

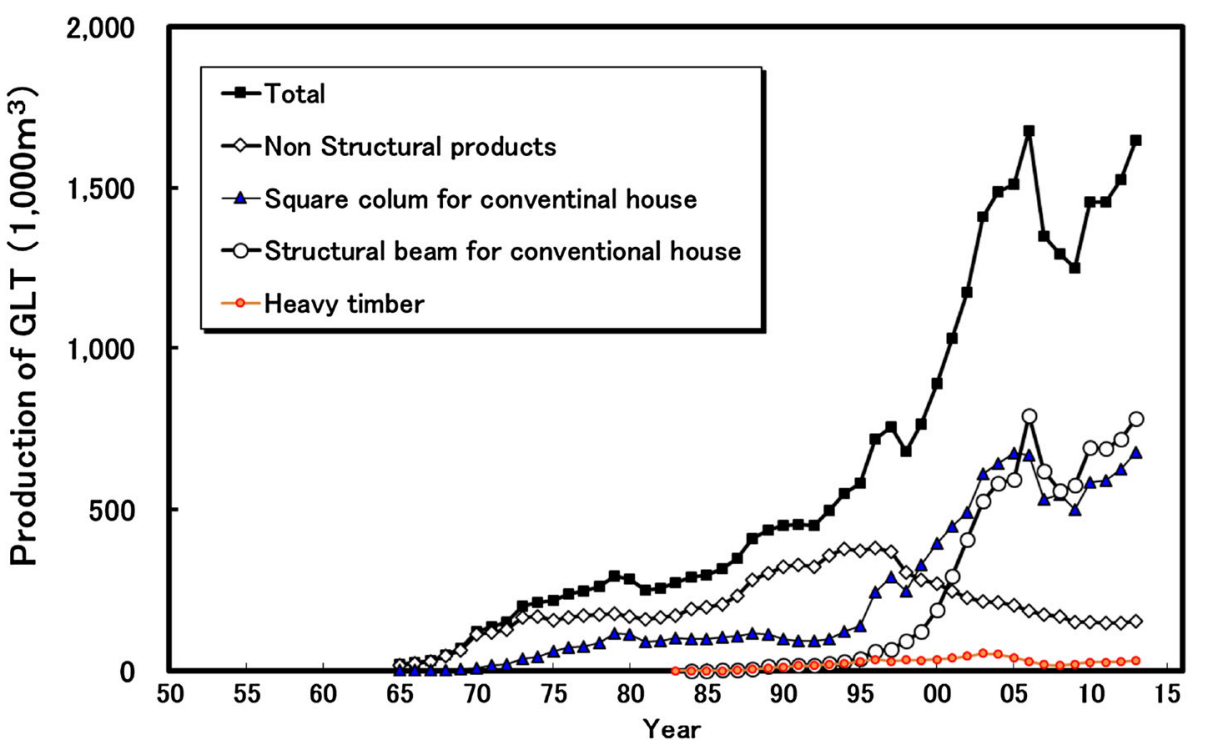


research institutes in Japan with the purpose of solving these manufacturing problems [7].

\section{Sugi composite glulam}

One of the drawbacks of sugi as a raw material for glulam is its lower strength properties than those of other imported species, such as Douglas fir from North America and red pine from European countries.

Table 1 shows the relation between species and the typical strength grades of glulam commonly used for columns or beams, where $E$ is the average MOE of the product and $F$ is the bending design strength. As is clear from this table, the strength properties of sugi glulam are lower than the others.

For improving the low strength properties of sugi glulam, the concept of "composite glulam" was introduced, in which other species of laminae having high MOE would be used for the outer layers (Fig. 2). As is widely known, even in the processing of common glulam, the laminae with high MOE are used for the outer layers, particularly in the tensile zone. This is because higher stress takes place at outer layers when a bending load is applied to the glulam. This simple principle was applied to the processing method of sugi composite glulam; other species of laminae with higher strength properties were investigated for application to the outer layers, while sugi laminae were used for the inner layers.

The idea regarding composite glulam, i.e., mixing two different species of laminae within the same glulam, is not novel. In USA, Biblis [8] reported the theoretical advantage of composite glulam nearly half a century ago, followed by Moody [9]. In addition, Braun [10] demonstrated that the design strength of small glulam beams with laminated veneer lumber (LVL) tension laminae was

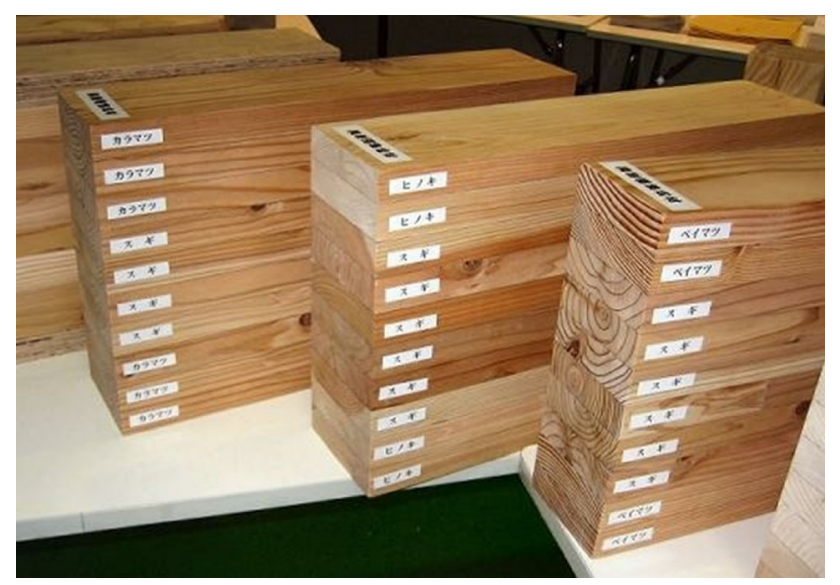

Fig. 2 Sugi composite glulam using karamatsu, hinoki and Douglas fir (from left to right)
10-20\% higher than those of glulam with normal lumbertype tension laminae.

In Japan, Hayashi and Miyatake conducted a series of studies on the strength properties of sugi composite glulam with Douglas fir LVL laminae, which have high-strength properties, and reported that their bending and tensile strengths were considerably higher than those of conventional sugi glulam $[11,12]$.

The first wood structure using composite glulam in Japan was the library of the Institute of Wood Technology in Akita Prefectural University, built in 1994. In this building, sugi composite glulam with Douglas fir laminae as the outer layer was used for the ascendant beams [13]. However, these sugi glulam beams were merely article-by-article products: not mass-produced glulam beams in accordance with JAS for GLT.

In 1996, JAS for GLT came to permit the production of composite glulam as far as the specific quality-control method using a probabilistic model was employed, but it was several years before a company began to produce the sugi composite glulam. Then, in 2002, two separate companies gained JAS certification for sugi composite glulam mixed with Douglas fir.

The commercial production of sugi composite glulam was thus underway, but the amount of production was insignificant due to the complexity of production management and the shortage of strength data on laminae, which were needed for quality control. Moreover, combinations of species other than sugi and Douglas fir were rarely considered; experimental data of other composite glulam were scarce.

Thus, a comprehensive research project was conducted at FFPRI for investigating the strength properties of the various composite glulam beams [7]. Nine prefectural research institutes participated in this research project. A lot of strength data of laminae with and without finger-joints were accumulated for preparing a strength database of laminae. The species prepared for the production of composite glulam were domestic todomatsu (Abies sachalinensis), ezomatsu (Picea jezoensis), karamatsu (Larix kaempferi), hinoki (Chamaecyparis obtusa), sugi, imported Douglas fir and Siberian larch (Larix gmelinii).

In conjunction with organizing the lamina database, many strength tests for composite and specific glulam using non-standard laminae that were not regulated by JAS for GLT at the time were conducted at the ten research institutes in Japan.

Combinations of the types of tested glulam and research institute were as follows: sugi glulam using non-standard laminae with low MOE, were tested at the Miyazaki Prefectural Wood Utilization Research Center, akamatsu (Pinus densiflora) glulam using non-standard knotty laminae 
at the Iwate Prefectural Forest Experiment Station, karamatsu glulam composed of edge-jointed laminae at FFPRI, hinoki glulam composed of edge-jointed laminae with a trapezoid cross section at the Okayama Prefectural Technology Center for Agriculture, Forestry and Fisheries, sugi composite glulam using sugi structural LVL at Miyagi Prefectural Forestry Technology Institute, and sugi composite glulam using konara (Quercus serrata) LVL at the Kyoto Prefectural Agriculture Forestry and Fisheries Technology Center.

Moreover, similar strength tests were also conducted on the glulam with non-standard cross-sectional configurations. These researches were conducted as follows: sugi, Douglas fir, and their composite glulam at FFPRI; todomatsu, ezomatsu, karamatsu, Douglas fir and their composite glulam at the Forest Products Research Institute, Hokkaido Research Organization; sugi, Siberian larch and their composite glulam at Toyama Prefectural Agricultural, Forestry and Fisheries Research Center and the Forest Products Research Institute; sugi composite glulam using karamatsu laminae at Nagano Prefecture Forest Research Center; sugi composite glulam using hinoki laminae at the Ehime Prefectural Forest Research Center; sugi composite glulam using Douglas fir laminae at the Hiroshima Prefectural Technology Research Institute and the Forest Research Center.

Results and conclusions obtained from these studies can be summarized as follows [3]:

1. Tested glulam composed of non-standard laminae had sufficient strength properties equivalent to standard glulam. These laminae can be used as far as special quality control is considered.

2. Glulam composed of edge-jointed laminae has equivalent strength properties to the same-grade glulam with standard laminae [14].

3. Bending strength of sugi, todomatsu and ezomatsu composite glulam is increased by the use of other species of laminae having high MOE for outer layers.

4. On the other hand, the tensile and compressive strength of the composite glulam are not so much improved as the bending strength.

5. Shear strength and partial compression strength can be predicted by the strength properties of the inner laminae.

6. Adhesive strength and delamination resistance between two laminae of different species satisfy the requirements of JAS for GLT.

7. Sugi composite glulam using sugi structural LVL as the outer layer satisfies the performance required for equivalent-grade conventional sugi glulam [15, 16].

8. Bending strength of sugi glulam can be much increased by the use of konara LVL [17].
In response to these results, the new strength grade named "mixed specific symmetric grade (ME grade)" was established in the JAS guidelines for GLT, and processing of composite glulam became easier than before. However, since the effects of high-strength laminae are limited to bending strength, the application of ME-grade glulam was limited to bending members such as beams and girders.

Unfortunately, a guideline for composite glulam using LVL laminae has not been established in the JAS for GLT so far, because the test data have been inadequate. More test data should be prepared regarding the combination of species of laminae and LVL.

\section{Quality assurance of glulam using Monte Carlo simulation}

The arrangement of laminae in a cross section of GLT is defined in JAS for GLT. In response to the arrangement, reference values for bending, tensile, compression and shear strength factors are assigned under the auspices of Japan's Ministry of Land, Infrastructure, Transport and Tourism.

In the case when the particular arrangement of layers is not defined in the JAS for GLT, some demonstrative experiments are necessary to prove that the product maintains strength performance higher than the target values. Besides these experiments, a probabilistic model using Monte Carlo simulation is necessary for quality control of the product.

The method for predicting the strength distribution of glulam by a Monte Carlo simulation technique was developed in North America [18]. The important advantage of this method is that strength distributions of glulam can be predicted without many full-size strength tests, which are time-consuming and expensive [19]. Basically, in this method, a lot of strength test data of the laminae are input in a computer simulation. Once the strength database of the laminae is completed, strength distributions of the glulam for any type of cross section can be simulated to some extent.

The first actual processing system for glulam was the "probabilistic beam design method" (PBDM), which strongly urged the development of similar systems in Japan. Various probabilistic models were proposed by Komatsu [20], Hayashi [21-23], Hirashima [24], Mihashi [25], and Mori [26].

Each model has its own features and details; however, the flow of such simulation programs can be simplified as follows:

1. Statistical analysis: for obtaining the strength distributions of raw materials, strength tests of bending, tension, and others are conducted on a quantity of 
laminae with and without finger-joints. Then, a statistical analysis for the data is conducted; the correlations among strength properties are calculated. For example, the correlation coefficient between bending strength and MOE is calculated with a lot of data.

2. Database of virtual lamina: a random number in accordance with the distribution of the MOE is generated in a computer; then, other random numbers simulating the strengths (bending, tensile and others) are generated taking into account the correlation between the generated MOE [27]. Virtual laminae consisting of a set of generated numbers are modeled with these Monte Carlo simulations. This process is repeated thousands of times to create a database of virtual laminae.

3. Virtual glulam: from this database, the virtual laminae are chosen in accordance with the assumed configurations of a cross section of glulam. Then a virtual glulam is created in the computer.

4. Virtual strength test: the virtual glulam is tested in bending, tensile and compression in the computer under the criterion for the failure of glulam: for instance, a bending failure takes place when the bending stress reaches the tensile strength of the outer laminae. At the same time, the bending stiffness (MOE) of the virtual glulam is calculated.

5. Prediction of real strength: the processes from 3 to 4 are repeated thousands of times in the computer. Then, thousands of virtual test data are obtained, which can be used for an estimation of the real strength distribution of the glulam.

As described in the former chapter, this estimation method is used for the actual quality-control systems of sugi composite glulam with different species of laminae. However, sugi composite glulam with structural LVL has not been accepted in the existing JAS for GLT due to the shortage of sufficient test data.

In addition, this method is also applicable to the processing of structural LVL [28] and cross-laminated timber [29], but simulation testing of these products has not been attempted so far.

\section{Sugi fire-retardant glulam}

On the revision of Japanese Building Standards Law in 2000, the basic concept of the law changed from specification provisions to performance provisions: for example, wooden high-rise buildings are permitted as long as the fire resistance of its elements is verified by official experiments. This drastic change has promoted research and development on wooden fireproof products [5].
A sugi glulam column (cross section: $300 \times 300 \mathrm{~mm}$ ) clad in three-layered gypsum board (thickness: $40 \mathrm{~mm}$ ) was developed in 2003. Although this glulam obtained the certification of 1-h fireproof performance, there was a demerit in that the surface of wood was invisible.

A wood-steel, hybrid-type product, namely, an H-section steel beam clad in glulam, was developed by Japan Laminated Wood Products Association in 2003 [30]. This product, made of karamatsu or Douglas fir glulam, also obtained the certification of 1 -h fireproof performance. Unfortunately, sugi was not used for the cladding due to its worse fire-retardant performance than karamatsu or Douglas fir.

Sugi fire-retardant glulam, in which inorganic mortar as fire-die-out layers were inserted between an ordinary glulam core and surface layers, was developed in 2008 [31].

Another sugi fire-retardant glulam using impregnated sugi laminae as a fire-die-out layer was developed in 2008 [32]. A fire-retardant chemical was impregnated into the lamina through holes bored by a $\mathrm{CO}_{2}$ laser incising machine [33]. This product (cross section: $300 \times 300 \mathrm{~mm}$ ) obtained the certification of 1 -h fireproof performance. Furthermore, it was found that the larger specimen (cross section: $410 \times 410 \mathrm{~mm}$ ) had adequate performance for the 2-h fireproof test.

Sugi fire-retardant beams using impregnated plywood as a fire-die-out layer were developed by the research groups at Akita Prefectural University and Waseda University [34].

Along with the development of sugi fire-retardant products, large-scale wooden structures with 1-h fireproof performance have been increasing, but the total number is still small due to its unreasonable cost. To increase the number of fire-retardant wooden structures, a reduction in the cost of fire-retardant products is essential.

\section{Conclusion}

Much effort has been made to expand the market for sugi. The research and development of sugi glulam reviewed in the present paper is a typical example. As a result of this research and development, many technical problems derived from the drawbacks of sugi have been solved, but several difficulties, such as a use of structural LVL for a lamina of glulam, remain. Moreover, the need to reduce the price of these products also remains.

Current research interests in the timber engineering field have shifted to cross-laminated timber; however, development of wood-based materials, such as glulam, structural LVL, structural plywood, and other structural composite products should be continued through collaborations between industry, academia, and government. 


\section{References}

1. Forestry Agency (2015) Statistics directory of forest and forestry 2014 (in Japanese). pp 8-9

2. Forestry Agency (2014) Forest and forestry white paper 2014:159 (in Japanese)

3. Miyatake A (2009) Utilization of sugi for structural glued laminated timber (in Japanese). Res J Food Agric 34:20-24

4. Japanese Agricultural Standard (2008) JAS for glued laminated timber (in Japanese). pp 1-42

5. Harada T, Kamikawa D, Miyamoto K, Ohuchi T, Miyabayashi M, Ando K, Hattori N (2010) Development of fireproof gluedlaminated timber for use in medium-rise building in Japan. In: Cruz (ed) Structure and architecture. Taylor \& Francis, London, pp 365-371

6. Hayashi T (2004) Recent development in processing technology on engineered wood products in Japan. In: Proceedings of the conference on forestry and forest products research 2003 (CFFPR 2003), 6-8 October 2003, Kuala Lumpur, Malaysia, pp 226-237

7. Forestry and Forest Products Research Institute (2009) Development and evaluation of new structural products using domestic species (in Japanese). FFPRI Grant Res Rep Ser No 23

8. Biblis EJ (1966) Design consideration for laminated wood beams composed of two species. For Prod J 16:39-51

9. Moody RC (1974) Design criteria for large structural gluedlaminated timber beams using mixed species of visually graded limber. USDA For Ser Res Pap FPL 236

10. Braun MO, Moody RC (1977) Bending strength of small glulam beams with a laminated-veneer tensile lamination. For Prod J 27:46-51

11. Hayashi T, Miyatake A (1991) Strength properties of sugi composite-glulam beams I (in Japanese). Mokuzai Gakkaishi 37:200-205

12. Hayashi T, Miyatake A, Hoshi T (1992) Strength properties of sugi composite-glulam beams II (in Japanese). Mokuzai Gakkaishi 38:247-255

13. Iijima Y (2011) The trend of glulam production (in Japanese). In: Institute of Wood Technology (ed) Concise encyclopedia of wood. Akita Cultural Publication, Akita, pp 94-95

14. Hiramatsu Y, Fujimoto K, Miyatake A, Shindo K, Nagao H, Kato H, Ido H (2011) Strength properties of glued laminated timber made from edge-glued laminae II: bending, tensile, and compressive strength of glued laminated timber. J Wood Sci 57:66-70

15. Fujimoto K, Hiramatsu Y, Miyatake A, Shindo K, Karube M, Harada M, Ukyo S (2010) Strength properties of glued laminated timber made from edge-glued laminae I: strength properties of edge-glued karamatsu (Larix kaempferi) laminae. J Wood Sci 56:444-451

16. Onishi Y, Miyatake A, Hiramatsu Y (2008) Strength properties of sugi LVL as a lamina of glulam. Abstract of the 58th annual meeting of the Japan Wood Res Soc, Tsukuba, p 24

17. Tabuchi A, Tsuchiya Y, Nagao H, Kato H, Ido H (2007) Strength properties of sugi composite glulam using Quercas LVL. Abstract of the 57th annual meeting of the Japan Wood Res Soc, Hiroshima, p 20

18. Foschi RO, Barrett JD (1980) Glued-laminated beam strength: a model. J Struct Div 106:1735-1754
19. Bender DA, FE Woeste, EL Schaffer, CM Marx(1985) Reliability formulation for the strength and fire endurance of gluedlaminated beams. USDA For Serv Res Pap FPL 460

20. Komatsu K (1997) Prediction of maximum bending moment of glulam beam composed of arbitrary laminae and verification by experimental results (in Japanese). Mokuzai Gakkaishi 43:934-939

21. Hayashi T (1990) Performance prediction of wood laminates by a probabilistic model IV (in Japanese). Mokuzai Gakkaishi 36:812-818

22. Hayashi T (1991) Performance prediction of wood laminates by a probabilistic model V (in Japanese). Mokuzai Gakkaishi 37:904-911

23. Hayashi T, Itagaki N, Oguro S, Nakajima Y, Machida H (2002) Prediction of bending strength of sugi medium dimension glulam beams by Monte Carlo simulation (in Japanese). J Soc Mater Sci Jpn 51:373-378

24. Hirashima Y, Yamamoto Y, Suzuki S (1994) Modeling for the strength of glulam beams and for their probabilistic distributions (in Japanese). Mokuzai Gakkaishi 40:1172-11795

25. Mihashi H, Itagaki N, Ito Y, Suzuki N (1996) Analytical model for the design of performance in glulam beams of Japanese ceder I (in Japanese). Mokuzai Gakkaishi 42:122-129

26. Mori T, Isoda H, Sasagawa A (2001) The proposal of the model for estimating the flexural strength of the glulam beam and verification by experimental results (in Japanese). J Struct Constr Eng Trans AIJ 541:51-57

27. Taylor SE, Bender DA (1989) A method for simulating multiple correlated lumber properties. For Prod J 39(7/8):71-74

28. Koseki M, Nakamura N (2012) Estimation of the strength distribution of elements for laminated veneer lumber by a nonlinear least-squares method (in Japanese). Mokuzai Gakkaishi 58:125-136

29. Okabe M, Yasumura M, Kobayashi K, Fujita K (2014) Prediction of bending stiffness and moment carrying capacity of sugi crosslaminated timber. J Wood Sci 60:49-58

30. Yusa S, Masuda K, Kawai T, Ohnuki T, Uesugi S, Namiki Y (2003) Fire resistance on hybrid wooden structure. Part 1. Experimental method on fire proof structural elements (in Japanese). Proc Jpn Assoc Fire Sci Eng Annu Symp, Tokyo, pp 106-109

31. Oka H, Ohashi H, Yamaguchi J, Hori N (2008) A study on selfcharring-stop of glued laminated timber made of Japanese cedar installing mortar piece (in Japanese). Bull Jpn Assoc Fire Sci Eng 58:13-20

32. Harada T, Hattori N, Ando K, Miyabayashi M (2007) Fire-resistance of fire-retardant impregnated laminated lumber. Proceedings of 11th international fire science and engineering conference, London, No. 1, pp 765-770

33. Hattori N, Ida A, Kitayama S, Noguchi M (1991) Incising of wood with a 500 watt carbon-dioxide laser. Mokuzai Gakkaishi 37:766-768

34. Ishikawa $\mathrm{T}$, Itagaki $\mathrm{N}$, Harada $\mathrm{K}$, Hasemi $\mathrm{Y}$, Nakamura $\mathrm{N}$, Okazaki Y, Hayashi T, Iijima Y (2014) Examination of a proper size of the burning margin in fire resistant wooden beam of a selfcharring stop type part 2 . Study of a beam with large height of a section. Summaries of technical papers of annual meet of Architectural Institute of Japan, Kinki, No. 3123, pp 277-278 